\title{
Embedding Preparedness, Assigning Responsibility: The Role of Film in Sociotechnical Imaginaries of Civil Defence
}

\section{Peter Bennesved and Casper Sylvest}

By the late 1950s and early 1960s, it was common for anti-nuclear campaigners and government officials alike to complain about public apathy towards the nuclear threat. Explanations offered for this nuclear withdrawal displayed some similarities, although their implications were poles apart. Public intellectuals like Günther Anders and Lewis Mumford essentially faulted the alienating dynamics of modernity and capitalism (van Munster and Sylvest 2016), whereas a 1962 US National Research

P. Bennesved $(\varangle)$

Department of Historical, Philosophical and Religious Studies, University of Umeå, Umeå, Sweden

e-mail: peter.bennesved@foi.se

C. Sylvest

Department of History, University of Southern Denmark, Odense, Denmark e-mail: csy@sdu.dk

M. Cronqvist et al. (eds.), Cold War Civil Defence in Western Europe, https://doi.org/10.1007/978-3-030-84281-9_5 
Council report on Behavioral science and civil defense suggested that widespread anxiety led to an unwillingness to confront difficult questions (Baker and Cottrell 1962: 75-76). Commenting on the latter study, Spencer Weart concluded in the mid-1980s that 'up to a point, most people could understand what war might really mean', but soon after 'the imagination rebelled' (Weart 1987: 20). In sociotechnical imaginaries of civil defence during the Cold War, the role of film was to assist the imagination in order to recruit and educate and to do so in a manner that provided hope and reassurance and served the political objectives with which civil defence organisations were invested. Visual media were central to public information campaigns at a time when cinema audiences were substantial and television began to make inroads in Western societies. Expanding state apparatuses had already exploited the potential of film during the Second World War. In the atomic age, inaugurated in popular consciousness by the bombings of Hiroshima and Nagasaki in August 1945, state-sponsored film found a new territory.

The study of civil defence films has had an American tilt, which reflects the central standing of the USA at the time and the postwar dynamics of Americanisation. Their differences notwithstanding, American films rehearsed a familiar theme: something could be done, and preparation was of the essence (e.g. Masco 2008; Jacobs 2010; Matthews 2012; Nowak 2016). Historians have initiated studies of civil defence films in other parts of the Cold War West (e.g. Cronqvist 2008; Norén 2012; Grant 2013; Bennesved and Norén 2020), and scholarship in this area carries significant potential for deepening our understanding of the similarities and differences of national civil defence efforts. Neutral Sweden and NATO-allied Denmark differed significantly in terms of civil defence in the postwar decades. ${ }^{1}$ Still, their close relationship in the immediate postwar years and their increasingly divergent positions in the Cold War present an opportunity to break out of national narratives. Like the technology that came to define it in the nuclear age, civil defence and its associated cultures were transnational phenomena (also Berger et al. 2018). Against this background, it is the ambition of this chapter to place the study of civil defence films in a transnational framework and to initiate efforts of comparison through a theoretically informed study of films produced in Sweden and Denmark during the early nuclear age (c. 1949-1965). We conceptualise civil defence as a sociotechnical imaginary and focus on the role of film in processes of embedding during the early nuclear age. We ask: What was the function of film in these two 
countries in embedding an imaginary of civil defence before and during the thermonuclear revolution? And how was the film medium exploited to structure the imagination of nuclear war and ways of surviving such a catastrophe?

Underlying our analytical strategy and the decision to analyse early (c. 1949-1954) and later films (c. 1954-1965) in this period is a historically informed assumption revolving around the development of thermonuclear weapons technology: though irregular and occasionally unsystematic, the general drift of civil defence thinking during the late 1950s was towards increasing individualisation of responsibility. ${ }^{2}$ Whereas early postwar civil defence witnessed much continuity with the concept of aerial protection-signalling an uneven adjustment to the risk of atomic warfare - the mid-1950s was marked by new, fraught questions about the nature of $\mathrm{H}$ bomb warfare. What protective measures were available against the immediate and longer-term effects of these unfathomable bombs at a time when new means of delivery were clearly on the horizon-and were available measures credible? Such questions became central to civil defence. Over time, they gave rise to new policies. In this process, collectively organised civil defence efforts and notions of civilian preparedness and responsibility were transformed. This transformation appears to have been central to the subsequent reshaping of civil defence in the 1970s and 1980s, yet our main focus is on determining whether, how and with what consequences this trend is reflected in filmmaking of the early nuclear age.

\section{SOCIOTECHNICAL IMAGINARIES AND VISUAL HISTORY: CIVIL DEFENCE FILMS AS PRACTICES OF EMBEDDING}

The concept of sociotechnical imaginaries is promising for advancing civil defence history (see Introduction, this volume; Jasanoff and Kim 2015; Jasanoff 2015a). While civil defence in Sweden and Denmark can be analytically approached as imaginaries in their own right, it is also apparent that these organisations played a part in upholding a wider vision of stability and progress, in part by containing and curbing the considerable risks of Cold War security politics. In this section, we attune the concept of sociotechnical imaginaries to the study of films and television. Though visual material took many forms and was used for a host of purposes, we focus on moving imagery about civil defence produced by state authorities and their associated partners intended for education, 
instruction, recruitment and propaganda. We zoom in on one particular dimension of such imaginaries: the study of intended use of visual media for embedding purposes, which we conceive as a combination of material structures and artefacts, a thoroughly technologised set of activities and a state of mind. We argue that the study of films harbours a potential to harness and refine the approach set out by Jasanoff and Kim (2015). We make three theoretical contributions.

First, a significant part of the conscious effort to embed postwar imaginaries of civil defence in Sweden and Denmark was centred on film, a potent medium for recruitment and information aimed at large audiences. Jasanoff develops the concept of embedding primarily with reference to the 'production of things' or collective forms of 'remembering' that transform 'the merely imagined into the solidity of identities and the durability of routines and things' (Jasanoff 2015b: 329, 323). While she places considerable theoretical emphasis on ways of seeing and the role of perception (Jasanoff 2015a: 13-14), she does not explicitly mention film among psychosocial forms of embedding. We contend, however, that moving imagery is important precisely because it is endowed with special properties in relation to authenticity, anticipation, persuasion and disciplining. ${ }^{3}$ In doing so we draw on and contribute to existing scholarship that has focused on the dissonances of emotion management in film (for example, in relation to fighting apathy, sustaining attention and avoiding panic).

Here we draw inspiration from Carey's $(2008,1989])$ idea of a balance between two views of communication: the ritual view and the transmission view. The films we study cannot be reduced to containers of information about a dominant imaginary. Embedding through moving imagery may (on the ritual view) be associated with and reflective of the continuous creation of community, fellowship and social norms. Repetition is central to such practices. The transmission view, on the other hand, is more closely tied to instruction, often for purposes of disciplining and control. Although both views of communication are typically present, the analytical value of the distinction lies in the recognition that 'communication is a symbolic process whereby reality is produced, maintained, repaired, and transformed' (Carey 2008: 19). This is no less true of visual communication. Hence, we pay attention to an entire life cycle of film production, from decision, financing, production and dissemination right up to the social and cultural practice of viewing. We focus especially on the latter, identifying a gradual shift during the 1950s away from films 
circulated through civil defence organisations and cinemas towards the comparatively new mass medium of television. We identify an overlap between a shift of content and message and a shift in media and circulation. The transition away from ritualistic methods of organised public film screenings towards transmission of information into the home of citizens was accompanied by a new balance of responsibility for in civil defence. In short, our point is related to McLuhan's (1964) famous dictum that the medium is the message.

Our second and third contributions require less elaboration. Although Jasanoff (2015b: 226-230) points out that embedding is not a smooth process, the place of this phase alongside other phases in the framework introduces a risk of flattening dissonance and crises. By reading films in the specific national contexts in which imaginaries of civil defence were conceived, practised and promoted and by focusing on a period of contestation and transformation, we highlight crises and complexity. Moreover, our attention to the connection between media and messaging can shed light on (some of) the ways in which imaginaries undergo transformation. Given the severity of the challenge to the concept of civil defence during the 1950s, we examine how and how successfully moving imagery sought to assist the imagination of audiences in negotiating leaps between the present and the future, fear and hope, realism and utopianism. Our focus in this endeavour is predominantly on the content of the films, yet we also pay attention to pace, editing and music where relevant. ${ }^{4}$

Finally, we draw on Lee Clarke's concept of 'fantasy documents', which was originally developed with reference to detailed plans for managing disasters. One of the properties Clarke ascribes to fantasies is an ability to shape meaning and behaviour, a perspective that is compatible with the concept of imaginaries. Clarke's analysis, however, emphasises the role of assumptions and scenarios. Indeed, fantasy documents seek 'to transform uncertainties into risks, rationalizing problems previously outside the realm of systematic control' (Clarke 1999: 11). Some civil defence films produced in the 1950s and early 1960s can be read as fantasy documents, we suggest, exactly because they presented 'live' crises to which citizens and organisations responded (and, in the case of the films we have studied, successfully so). The most potent method by which the films achieved this effect was by specifying threats through scenarios. These anticipations of the crisis were typically informed by assumptions that, although within the bounds of possibility, were both contestable and also, especially in the early 1960s, contested. Approaching filmmaking from this perspective 
brings out more clearly its role in (successful or unsuccessful) embedding practices.

It is with these theoretical ambitions in mind that we approach Danish and Swedish films produced or co-produced by civil defence authorities or volunteer organisations (working closely with the state). The number of Danish films-produced by the Danish Civil Defence Directorate (DCDD, Civilforsvarsstyrelsen) and the Danish Civil Defence League (DCDL, Civilforsvars-Forbundet) with state involvement ${ }^{5}$-is modest, and we have included most of the 10-12 films produced during the period. The number of Swedish film productions is considerably higher $(+30)$ and harder to specify, since several of these were co-productions between a wider range of authorities (including the military and the firefighting services). Not all of these films, however, were intended for the wider public. Following a screening of a majority of the available films and a process of triangulation with civil defence journals, newsletters and archival material, we identified a number of films that we have used as the primary materials for our analysis. ${ }^{6}$

\section{EARLY FILMS (C. I949-I954)}

Both Swedish and Danish civil defence authorities placed a premium on the use of film during the early 1950s, and they spent a considerable amount of energy and funds on producing films for purposes of recruitment and propaganda. ${ }^{7}$ Danish authorities were under financial constraints, whereas the Swedish system was more flexible and better funded (Norén 2012: 35-46). In both countries, however, there was considerable continuity both in relation to the use of the film medium stretching back to the interwar period and in relation to an established framework of Second World War aerial defence. The films also display many of the traits that are associated with the early development of the genre (Aufderheide 2007: ch. 1). Dramatic sound (drums, shrieking bombs, air-raids, music), a voice of God and an instructional modality are central characteristics.

In productions from both countries, the specific threat posed by the atomic bomb plays only a marginal role. Despite discussions about the radical nature of the atomic bomb, within civil defence organisations it gradually came to be seen in the framework of the strategic bombing known from the Second World War. Radioactivity was often mentioned as a special property of this technology, but it was not accorded much 
weight. Such factors conspired to keep much planning and certainly a substantial part of the existing imaginary of the next (aerial) war intact. Hence, civil defence authorities incorporated the atomic threat into an existing set of practices and maintained the emphasis on collective organisation. ${ }^{8}$ In other words, Danish and Swedish civil defence organisations functioned essentially in the same way in 1950 as they did during the war-only they were more extensive, better equipped and better drilled. War loomed large in the background, and it was unquestionably conceived to be catastrophic. But it remained an un(der)specified phenomenon, corresponding to a sense of unease and Angst, which recruitment efforts appealed to.

These features were mirrored in the films' manner of circulation. Both countries struggled with the dissemination of instructions and propaganda in written format and soon turned to other media (Bennesved and Norén 2020; Sylvest 2018). Moving imagery came to play an important role here, yet the specific circumstances of viewing are significant. ${ }^{9}$ Screening films in social settings involved both limitations and a normative commitment that fitted the underlying imaginary. In local associations, film screenings were cumbersome, since they required expensive equipment and film distribution. To solve this problem, civil defence organisations in both Sweden and Denmark began offering cheap or freeof-charge rental services by mail as well as film tours. ${ }^{10}$ Still, the function of films hinged on the willingness of citizens to gather and respond to the message, whether in local associations or at the cinema (where audiences were larger but presumably also less motivated). Local associations constituted an important site of screening in which recruitment was combined with curating, educational activities and exercises in a social setting in an effort to inspire and impose norms. ${ }^{11}$ Strikingly, this way of organising and distributing early films reflected their core message: civil defence was seen as a collective effort in which it was incumbent on citizens to gather and organise under the watchful eye of the authorities in order to help themselves, their fellow citizens and their country during war.

Looking closely at the content of the films, civil defence is portrayed in part as an insurance policy against unforeseen events and in part as a natural extension of existing social practices. There are few references to the specific nature and causes of war, but the films imply that the next war will be total in a new way; yet this phenomenon is typically visualised by scenes from the previous war. ${ }^{12}$ Consequently, a vague fear of the Cold War turning hot is pervasive, while the arrival of war is 
described as something beyond national control. The embedding efforts of these early films are dominated by an elaborate, state-led social organisation of human resources in protecting the homeland. The rationale and efficiency of collectively organised civil defence is displayed in a myriad of ways, but some are especially prominent and revealing of the imaginary informing these newly reorganised and renamed organisations. Four interrelated strategies stand out: the display of technologies and material resources; the seamless nature of the civil defence organisation and its transition from peace to war; a powerful image of efficiency based on the utilisation of technology and human resources; and, finally, a representation of volunteering as symbolic of a positive, imagined future for citizens.

The first of these strategies for communicating a message of competence and reassurance manifested itself in the display of a plethora of modern technologies, ranging from aircraft, trains, trucks and telephones to more mundane artefacts such as fire hoses. The distinctively modern look of specific artefacts or their mere abundant existence was used to signal organisational efficiency. In the Danish film Protecting the Population (Befolkningens beskyttelse, 1953), for example, almost a minute of the ten-minute information and recruitment film is taken up with panoramic views of the technologies necessary for facing the spectre of modern war. Swedish films communicate a similar message by zooming in on a civil defence organisation operating underground. Displaying hitech equipment and the operation of collective organisations was central to the imaginary of defending the homeland. An emphasis on scale hints at the national purpose and positions of the Danish and Swedish authorities (local and state) as guardians of its citizens. Identification is achieved through elaborate descriptions of the organisation of civil defence (including its various functions and branches, as well as charts of local organisations) and demonstrations of the smooth efficiency of the machinery in action. Among several objectives, the films sought to instil confidence in a collective, technocratic and hierarchically organised effort.

The second strategy revolves around the seamless nature of the collective social organisation and its transition from peace to war. This logic is visualised in the Swedish film Bombed Town (Bombad stad, 1949), a popular film at the time. ${ }^{13}$ A highly technologised set of activities are used to demonstrate the efficiency of civil defence, from military radar observation centres and alarms to the evacuation of citizens into urban 
air-raid shelters and firefighting activities in the aftermath of an air-raid. Reflecting a general trend, the scenario is based on a conventional (rather than atomic) attack from the air ('a massive attack, around 50 planes' as it is stipulated in the Swedish production Bombad stad from 1949). Core themes of anticipation, control and order shape the imaginary. Phones, trains, observation posts and air-raid shelters are not only perfectly organised, but also function flawlessly in concert with personnel that under strict emotional control handle everything by the book. In these highly stylised but underspecified scenarios, the early films acquire some of the qualities that Clarke associates with fantasy documents. Thus, when the bombs fall, the element of surprise is sometimes missing-both for the enemy and the audience (in one Swedish production, the evacuation train even leaves shortly before the alarm goes off). A ticking clock in the background emphasises order and anticipation, adding to the image of control. Consequently, the damage is reduced, lives are saved, and the necessity and efficiency of civil defence are validated. ${ }^{14}$

The first and second strategies are both undergirded by a strong social (and ethical) creed that spoke to the national communities and the bonds between citizen and state, typically through simple yet powerful analogies between the private and the public spheres. Protecting the Population (DEN 1953) explicitly extended care in the private sphere to the entire national community. Having opened with displays of maternal care and vigilance in relation to children, the film ends by admonishing the audience that ethics of order, vigilance, preparedness and humanitarianism 'is so natural when it concerns the little ones, but it also applies to grownups, for everyone, for all in this country that is worth preserving. ${ }^{15}$ Similarly, in the Swedish film Evacuation of Urban Centres (Utrymning av tätort, 1950), evacuation routines clearly mimicked conventional forms of social organisation. Families were split from individual family level up to the societal level; men were sent into the military organisation and women into the social and healthcare system, while children were evacuated from the cities with their schools. In a similar manner as Marie Cronqvist identified a civil defence organisation of the 1950s saturated with welfare-state symbolism, an imaginary is promoted and sustained in these films through existing social norms and moral coda. ${ }^{16}$

The third strategy on display in the early films revolved around a tight bond between social organisation and the technologies that saturated the imaginary. Human resources are not only technologised, but 
are also compartmentalised so that they can be harnessed within a hierarchical, specialised structure. As a result, the efficiency of civil defence organisations is amplified. Humans are equipped with and master modern technologies of transport, communication and firefighting. Officers use phones for orders and reports, and workers in uniforms use drills and welding equipment to free trapped civilians. A scene in the Swedish film Bombed Town subtly connects the social and technological dimensions of civil defence. In a meeting between an elderly couple, the Berggrens, who had their homes bombed, and a young female civil defence volunteer in a civil defence service centre, Mr Berggren's social status is described with reference to his technical skills. Consoling the bereft couple, the young woman smilingly exclaims that Mr Berggren is a welder, and thus worth his 'weight in gold'. The couple remains uneasy but nevertheless accepts their situation while the young civil defence official ends the conversation by shouting: 'NEXT!'17 The conversation here not only valourises the technical and technological skills of workers, but also highlights how the (gendered) social skills of the young official allow her to console fellow citizens, contain their discontent and inspire a restrained, positive attitude.

Fourth and finally, since public confidence in civil defence and/or the recruitment of volunteers were constant concerns, early films celebrated the humanitarian spirit of volunteers and their devotion to the noble cause. In depicting imagined futures where such qualities were on display, filmmakers walked a tightrope. They played on fears of war and catastrophe but also used this nightmare vision for socially useful, regenerative purposes. This Janus-faced character of embedding the imaginary was apparent from the outset, and it had implications for recruitment strategies. In the Danish case, the initial plan was to recruit hundreds of thousands of volunteers. ${ }^{18}$ The very first civil defence film sought to draw them in by playing on fears of war and using 'powerful effects' while maintaining what the director called a 'positive' tone. ${ }^{19}$ In several productions, the narrative revolved around a protagonist of civil defence work encountering an apathetic or ignorant character in need of conversion. ${ }^{20}$ The films provided that by pressing the analogy between good and rational behaviour in everyday life and in circumstances of catastrophic war. In the Swedish case, in which recruitment was less of a problem because of compulsory drafting from 1944, citizen confidence in state efforts was of greater importance. In the closing scene of Bombed Town (1949), a couple going to bed reflects on their anger with compulsory civil defence activities the previous year. Having survived a bombing raid, 
however, they express their gratitude towards the state. In Bombed Home (SWE, Bombat Hem, 1950) viewers are presented with a tense and slightly confused atmosphere in a shelter during an (unspecified) aerial attack. Order is imposed by a uniformed woman who directs the sheltered citizens and instructs fellow civil defence personnel. ${ }^{21}$ In such contexts, the uniform functioned as a symbolic and material manifestation of successful recruitment and as a marker of competence and authority. Displays of authority, however, were also tempered by the commonality among citizens and civil defence personnel. Towards the end of the film, uniformed and non-uniformed citizens emerged arm-in-arm from the ordeal into a destroyed urban area. ${ }^{22}$ Such messages of reassurance achieved through a display of both formal, skilled authority and community and familiarity were common in early filmmaking.

In sum, the core message of early Swedish and Danish films revolved around the mantra, ritually repeated on screen, that collectively organised preparation for catastrophe was essential, necessary, rational and the best available measure for avoiding panic and death. By mirroring the social order of society within a hi-tech civil defence organisation that valued technical skills and appealed to an existing moral economy in efforts to secure public support and draw in volunteers, these films sought to embed an imaginary of civil defence that displayed considerable continuity with recent experiences of war. The collective, uniformed and state-controlled national effort was deemed crucial for survival. Distinct roles were performed by individuals according to age, gender, class and function, yet this stratification served to reinforce a collective, national and humanitarian effort.

\section{LATER FILMS (C. I954-I965)}

By the early 1960s, civil defence films in Denmark and Sweden had taken on a new character. They struck a different tone. The opening scene of the Danish production Radioactive Fallout (DEN, Radioaktivt nedfald, 1961) is an instructive example. Set on a beach to unnerving music, the speaker addresses the viewers directly and asks them to reflect on the possibility that what we fear most-the dropping of an atomic bombmay become reality. 'You don't want to imagine this? Is that what you are thinking?' The film then proceeds to assist the imagination of the viewer. The transformation embodied in Radioactive Fallout did not occur overnight, and it arguably had its roots in the gradual and uneven 
response to the thermonuclear disruption of civil defence that was inaugurated by the US Castle Bravo test on Bikini atoll on 1 March 1954. Step by step, information and a string of worries about the $\mathrm{H}$ bomb made their way to the public sphere. In both Sweden and Denmark, it was soon apparent that this new weapons technology could potentially have enormous implications for civil defence, partly because of the sheer power of thermonuclear weapons and partly because of a new property that followed in its wake: radioactive fallout. Danish and Swedish authorities did not react immediately. The consequences of the disruption took time to gestate and only began to show towards the end of the decade following an intense period of information gathering and strategic deliberation. On film, it translated into a shift in tone and message: the later films focus explicitly on the nuclear threat, they struck a new balance between the responsibility placed on organised civil defence and that of the ordinary citizen, and they evinced a far more complicated and darker vision of life during and after a catastrophe.

Film kept its status as an important tool in embedding practices, as the rate of production testifies. Towards the late 1950s, the number of productions went up, and increasingly they moved away from the idealtypical features of the early films. In Sweden, several productions dealt with the exposure of urban environments to atomic weaponry, evacuation and the Swedish air-raid shelter system (especially large-scale population shelters and radioactivity). ${ }^{23}$ Danish productions, though smaller in number, display a similar pattern: films produced during the late $1950 \mathrm{~s}$ and early 1960s were more forthright in acknowledging the nuclear dimension of civil defence. ${ }^{24}$ The changing message was accompanied by a shift in production and screening practices in both countries. Films were still made for cinemas or available for screening in local associations, but civil defence organisations increasingly turned towards the television medium. In 1958, Swedish authorities also rejected a series of films produced during the early 1950s, branding them outdated and inappropriate. ${ }^{25}$ In Denmark, the transition was more gradual, and productions up until 1959 continued to pass on advice of the Duck-and-Cover variety that US authorities had declared retrograde. ${ }^{26}$

This shift in the dominant imaginary of civil defence was mirrored by changes in the media landscape and the prevalent view of communication. In contrast to the early period, where the circulation of civil defence films was marked by a ritual form of communication, the hydrogen-induced age of risk management eventually became characterised by a trend towards 
communication as transmission. The turn to television in communicating preparedness to wide audiences signifies the shift. Eager to find new ways of disseminating authoritative information, authorities began educating and instructing all citizens, enabling them to secure their own survival. Famously, this was done through pamphlets distributed in several Western countries during the early 1960s (including Germany and the UK), but television broadcasts also became increasingly popular. Moreover, these strategies also worked in tandem. State television functioned as visual companions to the mass distributed leaflets. In Denmark, the pattern was similar, although as a small country it placed less emphasis on mass evacuation. $^{27}$

Where previously films had sought to draw citizens into a social organisation that would provide detailed information (and exercise) only in a second step, specific advice was now funnelled directly into the homes of ordinary citizens. Local civil defence organisations no longer functioned as mediators. Consequently, a symbolic gap emerged between the safely bunkered civil defence broadcaster and the public recipient. Recruitment was no longer a top priority. Authorities would do their utmost to assist the citizen in the struggle for survival, but the buck stopped with the responsible citizen. Efforts to embed the imaginary were, therefore, aimed at the 'general public' - typically understood as a household father and mother facing a television set in the relative comforts of their home.

The new political and technological context in which civil defence operated was also clearly reflected on screen. Gradually, from the mid1950s, the raison d'être of civil defence became a matter of (some) public controversy. Swedish civil defence witnessed a major change in tactics that reflected the significance of the hydrogen bomb and new means of delivery that drastically reduced warning time. At the same time, debates about the nature and properties of radioactive fallout transformed civil protection. During a period when individual responsibility attracted more attention, collective civil defence in Sweden came to revolve around two distinct methods of protection: preparedness evacuation of whole urban environments and large-scale nuclear-proof population shelters for those who remained (Cronqvist 2012, 2015; also Bennesved and Norén 2020). The effectiveness of both measures was, however, in dispute. ${ }^{28}$ The shift in Danish policy was slower and less explicit but was also reflected in public debate (Sylvest 2020). By the late 1950s, some peace activists and radicals viewed civil defence as wildly utopian in its focus on local, atomic 
(rather than thermonuclear) warfare, and even when civil defence organisations explicitly addressed questions of fallout, the reception was mixed. While several newspaper reviews, for example, commended Radioactive Fallout for providing specific advice, critical voices-from both left and right-questioned the film's scenario and implied that civil defence was outmoded or utopian. ${ }^{29}$ Thus, public debate in both countries increased the pressure for information and solutions, and authorities were increasingly criticised from two directions: one flank accusing civil defence of being in league with militarism and the other accusing it of being inadequate and outmoded.

This burgeoning criticism shaped the focus, message and format of films produced in the late 1950s and early 1960s. It is reflected in three features of filmmaking in the period. First, the films produced during this period often explicitly focused on the threat posed by atomic or nuclear weaponry. Two ideal-typical forms of this shift of focus are apparent (some films, of course, displayed a mixture of these). On the one hand, a number of films focused on the role of civil defence in the event of a smaller atomic attack, a scenario that displayed continuity with the portrayal of civil defence as a modernised air-defence structure. In such films, however, it was increasingly made clear that the speed of modern warfare made it essential for every citizen to ensure their own immediate survival - often through simply acquiring information on where to go. In Denmark the production Civil Defence (1959) is an example focusing on the general population's immediate survival through air-raid shelters and evacuation. ${ }^{30}$ In Sweden, films such as Also a City Problem (1960) similarly emphasised the necessity of having 'simple instructions' for the 'individual' in situations in which speed was of the essence. ${ }^{31}$ On the other hand, productions of the early 1960s tended to focus on the more complex scenario of defending Denmark or Sweden against the effects of thermonuclear war. Here war-rarely if ever involving a direct $\mathrm{H}$ bomb attack on either country-was portrayed as a meteorological phenomenon, with radioactive fallout silently and invisibly striking the country (rather than being the direct effect of an $\mathrm{H}$ bomb explosion). The most iconic films in this respect are Radiak (SWE 1962) and Radioactive Fallout (DEN 1961). These films are at once more futuristic, vague and sombre, and they involve an element of public education for the nuclear age. 
Second, it was during this period that civil defence films evinced a tendency to individualise responsibility for survival, which in turn transformed the role(s) of collective civil defence. The stress on individual responsibility had been apparent for some time in the USA, but with the hydrogen bomb, it gained ground across countries in the West. Significantly, NATO committees concerned with civil protection began pushing this agenda in the mid-1950s. ${ }^{32}$ Recruitment into volunteer organisations became less important. A redistribution of responsibility-generally speaking, from collective towards individual responsibility-involved difficulties. These problems concerned science education (necessary for understanding the properties of nuclear weapons technology) and how to make the effects of the $\mathrm{H}$ bomb intelligible. In these matters, filmmaking had to chart a course between inducing action and avoiding narratives that risked undermining the imaginary. Hence, it became a common strategy to use abstract visualisations, maps or other forms of modelling and experimental imagery. The properties and dangers of radioactivity and fallout were often visualised through drawings and cartoons. ${ }^{33}$ Similarly, the nature and effects of thermonuclear weapons were typically demonstrated by animations of nuclear explosions, sometimes in combination with footage from (US) tests. Despite their abstract nature, such sequences could be chilling.

Third, it was a characteristic strategy of the later films in both countries that they sought to mitigate the horrors of nuclear war by obfuscating politics and the causes of war while installing an ever-present risk of nuclear war into orderly and ordinary everyday life. Clearly, new weapons technologies placed new demands on civil defence, but the arrival of (thermo) nuclear war (just like the fallout that would follow) appeared as wind, clouds and rain with temporary effects. So while the risk of war is a pervasive feature of these films, the political nature of war is oddly absent and disconnected from the main message that preparedness is (also) an individual responsibility. Taken together, the films are emblematic of a drift of policy in Swedish and Danish civil defence at the time. In Sweden, self-protection was launched in earnest after 1960-1961. ${ }^{34}$ Soon after, in early 1962, Danish authorities finally informed the public about the dangers of (thermo) nuclear weapons and the consequences of their use. The filmic strategies designed for embedding this incarnation of 'preparedness' revolved around calm, well-prepared and methodical citizens taking responsibility for themselves and their families in times of crisis. 
When every citizen became a target-also of information-their conduct was depicted in new ways. In one Danish film from the period, the speaker intones that in modern war, the warning will be so short that you must seek shelter immediately'. ${ }^{35}$ The housewife, the farmer and the worker are typically unfazed on receipt of warnings about incoming attacks or fallout. Attentive to the instruction of authorities, they go about their duties in a highly disciplined fashion, whether they concern the safety of children, livestock or co-workers. In Sweden, the household car became a key technology that would ensure survival if kept with a full tank. This was, again, an individual responsibility decoupled from organised civil defence services. Television shows such as If the War Comes (SWE, Om kriget kommer, 1961) emphasised the housewife's role in processing instructions into practical pre-packed suitcases and evacuation routines. ${ }^{36}$ At some points, the instructions communicated through these examples produced dissonance and paradox. Indeed, some strategies of survival appeared to be remnants of the 'atomic age', if not outright inadequate, in the face of thermonuclear war: run, hide, close the door, wash yourself, and clean your cupboard. Yet, they could be justified within the parameters of official scenario planning. Still, the overall point - that citizens were to a large extent responsible for their own survival-appealed directly to social norms about responsibility in the family and the workplace. This is unlikely to have been lost on audiences.

Similarly, when every citizen became a civil defender, the collective dimension of civil defence took on a new guise. On screen, uniformed personnel still played a crucial role in defending the homeland and the population, but they increasingly appeared as a (bunkered) elite of cool experts that provided an early warning, directed or assisted evacuation efforts (if time permitted) or monitored levels of radioactivity. The siren was central and used to dramatic effect as both audio background and as a visual symbol of danger. Many sequences are rich with artefacts of organised civil defence; uniforms, trucks, firefighting equipment and communications technology are amply on display. Tactical considerations and decisions took on a prominent role; radar detection of enemy airplanes and telephone conversations appeared as central nodes in a network of activity that would ensure survival. Civil defence was still emblematic of the well-prepared society. In contrast to the earlier films, however, we now encounter visible signs of strain and exhaustion. As scenarios of catastrophe unfolded and as they were extended into an imagined future, life underground was depicted as manageable but also taxing 
and bleak. ${ }^{37}$ So while the distance between civil defence authorities and citizens increased and the balance of responsibility was reconfigured, the later films included an admission of the enormity of the challenge and its likely impact on both citizens and authorities. This increasing 'realism', however, was combined with a dogged insistence on the rationale of civil defence in the event of atomic and thermonuclear war. The significant leap between these two components of the imaginary was overcome by the use of highly specific scenarios. In conjuring up an entirely new form of warfare, assumptions were made about the nature and yield of weapons, the target, the weather, the resulting contamination and, even, the nature of the unforeseen circumstances that would occur.

It was at this point especially that these later productions-viewed as embedding efforts-came most closely to resemble fantasy documents. In a context of public scepticism and (assumed) apathy and faced with a new, formidable military technology, the problem was rationalised and brought under control through scenario building and simulation, often in specific, localised settings. This was not an entirely new strategy. Earlier films also operated with idealistic assumptions about an unfolding war, and there was still a premium on control in demonstrating efficiency and the necessity of the system. Crucially, however, the war depicted in the earlier films was a war that audiences understood through experience and collective memory. In contrast, the nature of thermonuclear war lay outside the realm of experience even as the fear of it could be very real. This was a premise of the later films that was reflected in their darker tone: personnel in underground structures, for example, continue to perform their duties despite the eradication of their entire hometown and its surroundings. ${ }^{38}$ Here, we encounter another dissonance: the later films are in a sense less fictional and achieve a quasi-realist effect by zooming in on hardship, unpredictability and the hazard of invisible, radioactive contamination, yet this effect was a product of an elaborate use of rationalisation through scenarios that, eventually, insisted on the possibility of survival. In the process, pressing questions about the nature of life in a postwar world were ignored. It was as if the crisis was over once measurements of radioactivity had returned to safe levels. In that sense, the films are not merely fantasy documents but also fantasy monuments. 


\section{CONCLUSION}

Our study has shown that Swedish and Danish filmmaking during 19491965 reflected a transition in both the imagination of future warfare and the rationale of civil defence. Following the thermonuclear disruption of the mid-1950s, the central imaginary of civil defence in both Sweden and Denmark underwent significant change in an effort to retain credibility. Although several mantras of civil defence persisted-including a dogged insistence on the value of preparedness and preparation-during the late 1950s and early 1960s, the national, collectively oriented legacy of aerial defence was transformed in both countries. A shift towards individualisation can effectively be read through film and television, which constitutes a rich source for studying imaginaries of civil defence and their embedding. Films produced towards the end of the period placed more emphasis on instruction and detailed information, while seeking to embed this new set of responsibilities in modernising societies and through shifting media cultures. They did so at least in part as a response to mounting political pressure for more information arising from national, transnational and international anti-nuclear movements.

The theoretical approach lodged in the concept of sociotechnical imaginaries has been productive especially in attuning us to the nature and dynamics of films as a form of psychosocial embedding. Moreover, it has allowed us to bring out just how closely technology and social norms were imbricated in visions of the next war. Still, important analytical and theoretical questions remain, and we are not absolved of grappling with thorny issues about the demarcation of imaginaries, the inescapable overlap between embedding and extension, or the precise influence, reception or effect of a particular imaginary. It is very hard to say something definite about such matters, and most empirical studies will be faced with questions about the representativeness of the source material and the reach of conclusions. In the context of empirical studies, these kinds of theoretical debates will persist and are to be welcomed. Yet, there are also more glaring pitfalls to avoid. In particular, the risk of producing a teleological narrative that reduces change to technological 'progress' appears especially pertinent. Staying true to the underlying logic of coproduction in the analysis of sociotechnical imaginaries is demanding, not least because it is a common inclination to identify social effects of specific 
technologies. The reverse dynamic-how social practices, norms, identities and institutions shape specific understandings of or responses to a technology—appears less habitual.

In our analysis, the process of (visual) individualisation of responsibility and its resulting changes in imaginaries of civil defence were not simply epiphenomena of technological change. Indeed, civil defence communication also shaped the public imagination of nuclear war and survival. The extent to which the films influenced the behaviour of the 'ordinary citizen' is impossible to determine, yet we should perhaps be wary of thinking too much along such lines that sustain a positivist approach to (visual) propaganda, information campaigns, or really any form of public narration by state representatives. In contrast, it may be more productive to approach these films as attempts at embedding. We are reasonably confident about the contours of the imaginary that civil defence authorities sought to advance, but less so about its subsequent fate. Here, we may lack a critical edge. To the extent that the approach and especially the sequential logic of the four phases in the life cycles of imaginaries appear infused with a logic of direction, progress, and perhaps even success, we ought to question it.

Indeed, the late 1950s and early 1960s can be read as the first phase of a long period of crisis that coincided with a growing criticism in Western Europe (and the USA) towards the self-proclaimed omnipotence of tradition and authority vested in state apparatuses. From this perspective, visualisations of the dominant imaginary of civil defence were rife with dissonances that, gradually, undermined its credibility. Individualisation was not a set trajectory, but perhaps rather a slow withdrawal from responsibility that pointed to a deeper crisis of faith inside and outside the ranks of civil defence organisations. Public criticism, declining membership numbers (Sweden had 660,000 volunteer members in 1945, and only 10,000 members in $1989^{39}$ ), decreasing state funding, rhetorical retreat in the face of Mutually Assured Destruction, and an orientation towards new peacetime activities point not to a mature and institutionalised imaginary of civil defence but rather to a lacklustre organisation of all-hazards risk management that could be openly defied and ridiculed. When civil defence organisations faced public scrutiny again in the 1980s, they certainly encountered such attitudes. While the emphasis on technology and the future that feature so prominently in the concept of sociotechnical imaginaries is clearly productive, there is also a need here to disturb 'the tidy timelines of progress' (Edgerton 2006: xii) that are 
associated with technology and stories of invention and adjustment. We are likely to gain more analytical power by approaching imaginaries of civil defence not as cyclical processes of successful adjustments and refinement but as a combination of ingrained reflexes and controversial political imperatives. From this angle, the imaginary of civil defence repeatedly encountered dissonance and crisis when it created images that reconciled life in the modern world with the dreaded future of nuclear war.

\section{Notes}

1. Sweden had already merged all civil defence activities into one organisation in 1944, whereas Denmark established its civil defence by law in 1949 .

2. See also Bjørnsson (ch. 2) in this volume. See also Oakes and Grossman (1992: 394-395) and Collier and Lakoff's discussion on the birth and evolution of 'Emergency federalism' (2008: 13-14). In relation to Sweden, Cronqvist (2012: 205-206) makes the case that civil defence did not experience 'privatisation', but perhaps 'state individualisation'.

3. We leave aside the difficulties of separating the dynamics of embedding and extension that emerge from Jasanoff's discussion (2015b). We appreciate the attempt to specify these dynamics, though they are often intertwined in (historical) practice.

4. Historians must pay attention to both aspects, or what Platinga (2005) terms the 'saying' and 'showing' parts of documentaries.

5. The relevant state agencies included The Film Committee of Danish Ministries (Ministeriernes Filmudvalg), Danish Cultural Films (Dansk Kulturfilm) and The Danish Government Film Office (Statens Filmcentral).

6. Swedish films are available through the Swedish Media Database, www.smdb.se [accessed 1 April 2020]. Most Danish productions are available through the Danish Film Institute: https://www.dfi. $\mathrm{dk} / \mathrm{en} / \mathrm{english} /$ danish-film-history [accessed 1 April 2020].

7. For Denmark, see DCDL to The Film Committee of Danish Ministries, 15 December 1950, in Old film records, 'Civilforsvaret', The Danish Government Film Office, Danish National Archives (DNA)/The Danish Film Institute (DFI); for Sweden, see Norén (2012: 43-45). 
8. See Bennesved (2020). This 'conventionalisation' of the atomic bomb and its reception into an existing set of practices comes out in several chapters in this volume. See especially Bjørnsson (ch. 2) and Farbøl (ch. 7).

9. Danish films were specifically produced for either cinema distribution or local associations. DCDD, Status for civilforsvaret, September 1953, 27-28. DNA, Schultz Memoranda 185. For the film plans of Swedish civil defence, see Norén (2012).

10. Indeed, from the mid-1950s, the annual reports of the DCDL contained information about the most popular films, and film catalogues were printed to service local associations.

11. See, for example, the following Swedish report from 1953: 'Civilförsvarsupplysning genom utomhusbio', Tidskrift för Svenskt civilförswar (1953), 75-76. For an analysis of similar trends in the USA and the UK, see Matthews (2012) and Hogg (ch. 4) in this volume.

12. See also the chapters by Bjørnsson (ch. 2) and Hogg (ch. 4) in this volume.

13. 'Från arbetsfältet', Tidskrift för Svenskt civilförsvar (1950), 22; See also letter to Arthur Dahl l October 1949, Vol. B VII: 14 'Brev från Danmark' Civilförsvarsstyrelsens öppna arkiv, Krigsarkivet, Swedish National Archives, Stockholm, Sweden.

14. However, on overly political matters, like the risk of Sweden maintaining a neutral and alliance-free stance in the postwar period, Bombed Town is silent.

15. Protecting the Population (DEN 1953), 10:05-10:15.

16. For more on the connection between Swedish civil defence and welfare politics, see Cronqvist $(2008,2012)$.

17. Bombed Town (SWE 1949), 18:00-18:40.

18. In 1951, the goal was to make 600,000 Danes 'civil defence conscious' (DCDL to The Film Committee of Danish Ministries, 25/6-1951. Old film records, 'Mit navn er Christensen', The Danish Government Film Office, DNA/DFI).

19. 'Draft of propaganda film for Civil Defence', Old film records, 'Civilforsvaret', The Danish Government Film Office, DNA/DFI.

20. See for example Women in Civil Defence (DEN, Kvinder $i$ Civilforsvaret, 1952) and in My Name is Christensen (DEN, Mit navn er Christensen, 1953).

21. Bombed Home (SWE 1950), 15:50-17:11. 
22. Bombed Home (SWE 1950), 29:00-29:05.

23. See for example We Move Underground (Vi går underjord, 1959), Also a City Problem (Också ett storstadsproblem, 1960) and Radiak (1961). The CDA also produced a series of evacuation films aimed at audiences in dense urban areas.

24. See especially Civil Defence (Civilforsvaret, 1959), Air Attack (Luftangreb, 1959) and Radioactive Fallout (1961) - the three most significant films of the time.

25. 'Nytt från Civilförsvarsstyrelsen, Kasserade filmer', Tidskrift för Svenskt Civilförsvar, (1958), 26.

26. See especially Air Attack (1959). On US advice, see Titus (1983: 6).

27. In this period, civil defence authorities in both countries also began producing and participating in television debates. In Sweden, following the successful show Our Need for Security (Vart behov av trygghet) in 1958, the CDA decided to work with television to launch a new self-protection campaign in 1961. Similarly, the previously mentioned film Radiak (1962) was from the start intended as a television broadcast: 'Radiak - tre nya filmer', Tidskrift för Svenskt Civilförsvar (1962), 85. Radioactive Fallout, the most ambitious and well-crafted Danish production, was broadcast on Danish Television on 6 December 1961, a month before the national distribution of the Danish leaflet.

28. In Sweden, criticism against civil defence was spearheaded by Aktion mot Svenskt Atomvapen, (AMSA), see Andersson (2001). Two veteran officers also criticised the then civil defence organisation as hopelessly inadequate causing much debate in public. See also Bennesved and Norén (2020).

29. See, for instance, reviews ('Rystende Realisme') in Jyllands-Posten, 8 December 1961 and ('Fra vort kælderdyb') in Frit Danmark, 1962, 20: 10, 14-15.

30. The film marked the 25-year anniversary of Danish civil defence. It followed an exercise based on a scenario in which a provincial town was attacked by a 'small atomic bomb'. Although there were clearly grounds for scepticism, the director sought to 'convince the viewer' of the effectiveness of civil defence in part through 'emotional appeal'. Carl Otto Petersen, 'Preface to civil defence film synopsis', 27 September 1958, Old film records, 'Civilforsvaret', The Danish Government Film Office, DNA/DFI. 
The film contained a much-ridiculed sentence from a failed information campaign of 1958; namely 'that the best protection is naturally to not be where the damage occurs' (4:10-4:16).

31. Also a City Problem, 1960, 12:50-13:10.

32. See Bjørnsson (ch. 2) in this volume.

33. Radioactive Fallout (DEN 1961) was commended for its animated, technical explanation of radioactive fallout.

34. Self-protection ('Självskydd') was officially endorsed in 1960 by the Swedish civil defence services, in preference to the older 'Hemskydd' model.

35. Civil Defence (DEN 1959), 3:15-3:23.

36. Broadcast on Swedish television on 10 October 1961.

37. See, for example, Radioactive Fallout and Evacuation of Vüsterås (SWE, Utrymning av Vüsterais, 1960).

38. For example, Our Need for Security (SWE 1958), 12:00-16:00.

39. Hans C. Pettersson, in Sjölin (2014: 207).

\section{REFERENCES \\ UNPUBLISHEd SOURCES}

RA: Rigsarkivet (Danish National Archives)

1261: Beredskabsstyrelsen, Civilforsvarsdirektør E Schultz’ embedsarkiv. 185: Memoranda

RA: Rigsarkivet (Danish National Archives)/The Danish Film Institute

Statens Filmcentral (The Danish Government Film Office)

Old Film Records

KRA: Krigsarkivet, Riksarkivet (Swedish National Archives)

0829: Civilförsvarsstyrelsen

Vol. B VII: 14

SMDB: Svensk Mediedatabas (Swedish Media Data Base): www.smdb.se

\section{WEBSITES}

Danmark på Film (Denmark in Films): https://filmcentralen.dk/museum/dan mark-paa-film

Filmarkivet (Sweden): http://www.filmarkivet.se 


\section{LiterATURE}

Andersson, Irene. 2001. En civilförsvarsvägran med rötter i 1930-talet. In När Alving blev Bang, ed. Marcos Cantera Carlomagno, 13-32. Lund: Historiska media.

Aufderheide, Patricia. 2007. Documentary film: A very short introduction. Oxford: Oxford University Press.

Baker, George W., and Leonard S. Cottrell, Jr. 1962. Behavioral science and civil defense, Disaster Study Number 16. Washington: National Academy of Sciences-National Research Council.

Bennesved, Peter. 2020. Sheltered society: Civilian air raid shelters in Sweden from idea to materiality, 1918-1940 and beyond. Malmö: Universus Academic Press.

Bennesved, Peter, and Fredrik Norén. 2020. Urban catastrophe and sheltered salvation: The media system of Swedish civil defence, 1937-1960. Media History 26: 167-184.

Berger Ziauddin, Silvia, Peter Bennesved and Sarah Robey. 2018. 'Living (again) in an age of nuclear fear: New avenues for studying Cold War civil defense', 16 April 2018. http://www.berlinerkolleg.com/sites/default/files/robey_ber ger_ziauddin_bennesved_cold_war_civil_defense_en.pdf [accessed 21 January 2020].

Carey, James W. 2008 [1989]. Communication as culture, revised edn London: Routledge.

Clarke, Lee. 1999. Mission improbable: Using fantasy documents to tame disaster. Chicago: Chicago University Press.

Collier, Stephen, and Andrew Lakoff. 2008. Distributed preparedness: The spatial logic of domestic security in the United States. Environment and Planning D: Society and Space 26: 7-28.

Cronqvist, Marie. 2008. Vi går under jorden: Kalla kriget möter folkhemmet i svensk civilförsvarsfilm. In Välfärdsbilder: svensk film utanför biografen, eds Erik Hedling and Mats Jönsson, 166-181. Stockholm: Statens ljud- och bildarkiv.

Cronqvist, Marie. 2012. Survival in the welfare cocoon: The culture of civil defence in Cold War Sweden. In Cold War Cultures: Perspectives on Eastern and Western societies, eds Anette Vowinckel, Marcus M. Payk, and Thomas Lindenberger, 191-210. New York: Berghahn Books.

Cronqvist, Marie. 2015. Evacuation as welfare ritual: Cold War media and the Swedish culture of civil defence. In Nordic Cold War cultures: Ideological promotion, public reception, and East-West interactions, eds Valur Ingimundarson and Rosa Magnusdottir, 75-95. Helsinki: Aleksanteri Cold War Series.

Edgerton, David. 2006. The shock of the old: Technology and global history since 1900. London: Profile Books. 
Grant, Matthew. 2013. Images of survival, stories of destruction: Nuclear war on British screens, 1945-c.1963. Journal of British Cinema and Television 10: $7-26$.

Grossman, Andrew, and Guy Oakes. 1992. Managing nuclear terror: The genesis of American civil defense strategy. International Journal of Politics, Culture and Society 5: 361-403.

Jacobs, Bo. 2010. Atomic kids: Duck and Cover and Atomic Alert teach American children how to survive atomic attack, Film \& History 40: 25-44.

Jasanoff, Sheila. 2015a. Future imperfect: Science, technology and the imaginations of modernity. In Dreamscapes of modernity: Sociotechnical imaginaries and the fabrication of power, eds Sheila Jasanoff and Sang-Huyn Kim, 1-33. Chicago: Chicago University Press.

Jasanoff, Sheila. 2015b. Imagined and invented worlds. In Dreamscapes of modernity: Sociotechnical imaginaries and the fabrication of power, eds Sheila Jasanoff and Sang-Huyn Kim, 321-341. Chicago: Chicago University Press.

Jasanoff, Sheila, and Sang-Huyn Kim, eds. 2015. Dreamscapes of modernity: Sociotechnical imaginaries and the fabrication of power. Chicago: Chicago University Press.

Masco, Joseph. 2008. Target audience. Bulletin of the Atomic Scientists 64(3): $22-32,45$.

Matthews Jr., Melvin E. 2012. Duck and cover: Civil defence images in film and television from the Cold War to 9/11. Jefferson, NC: MacFarland.

McLuhan, Marshall. 1964. Understanding media: The extensions of man. New York: McGraw-Hill.

Munster, Rens van, and Casper Sylvest. 2016. Nuclear realism: Global political thought during the thermonuclear revolution. Abingdon: Routledge.

Norén, Fredrik. 2012. Civilförsvarsstyrelsens filmaktiviteter under kallakrigsåren 1949-1952. Historisk Tidsskrift 132: 31-54.

Nowak, Lars. 2016. Images of nuclear war in US government films from the early Cold War. In Understanding the imaginary war: Culture, thought and nuclear conflict, 1945-90, eds Matthew Grant and Benjamin Ziemann, 260286. Manchester: Manchester University Press.

Platinga, Carl. 2005. What a documentary is, after all. The Journal of Aesthetics and Art Criticism 63: 105-117.

Sjölin, Vilhelm. 2014. I skuggan av kriget: svenskt civilförsvar 1937-1996. Stockholm: Instant Book.

Sylvest, Casper. 2018, Atomfrygten og civilforsvaret, temp - tidsskrift for historie 16: 16-39,

Sylvest, Casper. 2020. Nuclear fallout as risk: Denmark and the thermonuclear revolution. In Histories of knowledge in postwar Scandinavia: Actors, arenas and aspirations, eds Johan Östling, Niklas Olsen and David Heidenblad, 2138. London: Routledge. 
Titus, A. Constandina. 1983. Back to ground zero: Old footage through new lenses. Journal of Popular Film and Television 11: 3-11.

Weart, Spencer R. 1987. History of American attitudes to civil defense. In Civil defense: A choice of disasters, eds John Dowling and Evans M. Harrell, 11-32. New York: American Institute of Physics.

Open Access This chapter is licensed under the terms of the Creative Commons Attribution 4.0 International License (http://creativecommons.org/licenses/ by $/ 4.0 /$ ), which permits use, sharing, adaptation, distribution and reproduction in any medium or format, as long as you give appropriate credit to the original author(s) and the source, provide a link to the Creative Commons license and indicate if changes were made.

The images or other third party material in this chapter are included in the chapter's Creative Commons license, unless indicated otherwise in a credit line to the material. If material is not included in the chapter's Creative Commons license and your intended use is not permitted by statutory regulation or exceeds the permitted use, you will need to obtain permission directly from the copyright holder.

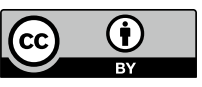

